\title{
Endodermal and Hepatic Differentiation from Human Embryonic Stem Cells and Human Induced Pluripotent Stem Cells
}

\author{
Kenji Kawabata ${ }^{1,2}$, Kazuo Takayama ${ }^{1,3}$, Yasuto Nagamoto ${ }^{1,3}$, Mary S. Saldon ${ }^{1}$, Maiko Higuchi ${ }^{1}$ and Hiroyuki Mizuguchi ${ }^{1,3,4 \star}$ \\ ${ }^{1}$ Laboratory of Stem Cell Regulation, National Institute of Biomedical Innovation, Osaka 567-0085, Japan \\ ${ }^{2}$ Laboratory of Biomedical Innovation, Graduate School of Pharmaceutical Sciences, Osaka University, Osaka 565-0871, Japan \\ ${ }^{3}$ Laboratory of Biochemistry and Molecular Biology, Graduate School of Pharmaceutical Sciences, Osaka University, Osaka 565-0871, Japan \\ ${ }^{4}$ The Center for Advanced Medical Engineering and Informatics, Osaka University, Osaka 565-0871, Japan
}

\begin{abstract}
Induced hepatocytes differentiated from human embryonic stem cells (ESCs) or induced pluripotent stem cells (iPSCs) have a wide range of potential applications in biomedical research, drug discovery, and the treatment of liver disease. Differentiation of human ESCs and iPSCs into endodermal and hepatic cell types has been achieved by several methods, including addition of soluble factors into culture medium, transduction of differentiation-related genes, co-cultivation with other lineage cells, and a three-dimensional culture system. Each of these methods has an advantage from various points of view, such as the degree of maturation of differentiated hepatocytes, differentiation efficiency, clinical safety, and ease of handling. Currently, it is possible to select or combine the differentiation protocols to obtain ideal hepatocytes. The aim of this review is to describe the recent progress in endodermal and hepatic differentiation protocols from human ESCs and iPSCs in order to foster the suitable choice of induced hepatocytes on clinical and industrial applications.
\end{abstract}

Keywords: Embryonic stem cells; Induced pluripotent stem cells; Liver; Definitive endoderm; Differentiation

\section{Introduction}

The liver has many functions, including carbohydrate metabolism, glycogen storage, lipid metabolism, urea synthesis, drug detoxification, production of plasma proteins, and destruction of erythrocytes. The liver is composed of several types of cells, including epithelial, endothelial, and hematopoietic cells. Of these cells, hepatocytes play the most important role in major hepatic functions. Hepatocytes are thus useful cells for biomedical research, regenerative medicine, and drug discovery. They are particularly useful for drug screenings, such as for the determination of metabolic and toxicological properties of drug compounds in in vitro models. For these applications, however, it is necessary to prepare a large number of the functional hepatocytes, which can no longer proliferate in in vitro culture. Isolated primary hepatocytes are the current standard in vitro model, because they express large amounts of drug-metabolizing enzymes and transporters [1]. However, isolated hepatocytes lose their differentiated properties, such as some cytochrome $\mathrm{P} 450$ activities that are induced by reference compounds, even under the optimized culture conditions [2,3]. Moreover, it can be difficult to set up long-term cultures with primary hepatocytes, because they can no longer proliferate in in vitro culture [4].

Human embryonic stem cells (ESCs) and induced pluripotent stem cells (iPSCs) are able to replicate indefinitely and differentiate into most cell types of the body, and have the potential to provide an unlimited source of cells for a variety of applications [5-8]. Among the differentiated cells from ESCs and iPSCs, induced hepatocytes have a wide range of potential applications in biomedical research, drug discovery, and the treatment of liver disease. In this review, we provide an up-to-date overview of the wide variety of endodermal and hepatic differentiation protocols. These protocols were designed to reconstruct the in vivo environment in a variety of ways, including by addition of soluble factors into culture medium, transduction of differentiationrelated genes, co-cultivation with other lineage cells, and use of a threedimensional culture system.

\section{Definitive Endoderm Differentiation from ESCs}

Gastrulation of the vertebrate embryo starts with the formation of three germ layers: the ectoderm, mesoderm, and endoderm. The endoderm contributes to the digestive and respiratory tracts and their associated organs [9]. The endoderm differentiates into various organs, including the liver, pancreas, lungs, intestine, and stomach. To examine the molecular mechanisms of endoderm specification during early embryogenesis, endoderm differentiation from ESCs has been widely investigated as an in vitro model [10]. It has been reported that mouse ESCs have the ability to differentiate into definitive endoderm (DE) cells [11-13]. In recent studies, specific growth factors are used to generate DE cells from ESCs. In DE differentiation, it is well known that nodal signaling plays a crucial role and induces the expression of endoderm-related genes [14]. Activin A, a member of the nodal family, is a ligand of the type II activin receptor and can transmit a downstream signal by using Smad adaptor proteins [15-18]. Therefore, activin A is widely used to generate DE from ESCs. Although embryoid body (EB) formation is also used in the differentiation of ESCs, activin A could generate DE more efficiently than the EB formation [19]. In addition, using activin A with other factors such as fibroblast growth factor (FGF) 2 or Wnt3a proved to be more effective. Simultaneous addition of activin A and FGF2 could synergistically promote more efficient DE

*Corresponding author: Dr. Hiroyuki Mizuguchi, Laboratory of Biochemistry and Molecular Biology, Graduate School of Pharmaceutical Sciences, Osaka University, 1-6 Yamadaoka, Suita, Osaka 565-0871, Japan, Tel: +81-6-6879-8185; Fax: +81-66879-8186; E-mail: mizuguch@phs.osaka-u.ac.jp

Received November 14, 2011; Accepted January 21, 2012; Published January 23, 2012

Citation: Kawabata K, Takayama K, Nagamoto Y, Saldon MS, Higuchi M, et al (2012) Endodermal and Hepatic Differentiation from Human Embryonic Stem Cells and Human Induced Pluripotent Stem Cells. J Stem Cell Res Ther S10:002. doi:10.4172/2157-7633.S10-002

Copyright: (c) 2012 Kawabata K, et al. This is an open-access article distributed under the terms of the Creative Commons Attribution License, which permits unrestricted use, distribution, and reproduction in any medium, provided the original author and source are credited. 
differentiation in comparison with using activin A alone [20,21]. It has also been found that DE differentiation was promoted by using activin A plus Wnt3a in comparison with activin A plus sodium butyrate [22].

Although DE differentiation methods using growth factors are useful strategies for generating DE with the ability to differentiate into hepatic or pancreatic lineages, they are not efficient enough for generation of homogenous DE populations [23,24]. To improve the DE differentiation efficacy, several groups have attempted a modulation of expression levels in endoderm-related transcription factors. It has been demonstrated that overexpression of SOX17, which is an integral transcription factor for DE formation, promotes $\mathrm{DE}$ differentiation, resulting in a DE differentiation efficacy of over $80 \%$ based on the estimation of c-kit/CXCR4 double-positive cells [24,25]. The FOXA2 transcription factor as well as SOX17 also functions as a crucial regulator of the initial intracellular signaling pathways in DE differentiation [26]. Overexpression of FOXA2 in ESCs enhances the efficacy of DE differentiation $[27,28]$.

\section{Hepatic Specification from ESC-derived DE cells}

Hepatic differentiation is divided into two steps: hepatic specification and hepatic maturation. In hepatic specification, DE differentiates into hepatoblasts that express a-fetoprotein (AFP), transthyretin, and albumin (ALB) [29-31]. At this stage, repression of Wnt signaling and FGF 4 is necessary for hepatic specification $[32,33]$. Also, interaction of FGFs with bone morphogenetic protein (BMP) 2 and BMP 4 is important for the induction of hepatocyte-related genes [34-36]. The combination of FGF4 and BMP2 promotes hepatic specification from human ESC-derived DE cells [37]. Similar results were obtained by using the combinations of aFGF and BMP4, bFGF and BMP4, or FGF4 and BMP4 [37]. It has been reported that heterogeneous hepatoblast populations could be differentiated from $\mathrm{DE}$ cells by using the combination of BMP2/4 and FGF1/2/4 [20]. With respect to the generation of homogeneous hepatoblast populations, several studies have demonstrated that this can be accomplished by modulating the expression levels of hepatocyte-related transcription factors as well as DE differentiation stage. Overexpression of HEX, which is an integral transcription factor for hepatic specification, has been shown to promote hepatic specification, with the result that the expression levels of ALB and AFP are up-regulated in HEX-transduced cells [38-40]. Conditioned medium from human hepatocellular carcinoma cell line, HepG2, could also promote the hepatic differentiation from human ES cells [41].

\section{Hepatic Maturation from ESC-derived Hepatoblasts}

Hepatoblasts differentiate into two distinct lineages, hepatocytes and cholangiocytes. During the fetal hepatic maturation, the number of hepatoblasts decreases, and in turn, the number of mature hepatocytes increases [42]. In this process, AFP is highly expressed in the fetal liver, and then the number of AFP-positive cells decreases in a later maturation step and almost disappears in the adult liver [43,44]. Growth factors that are secreted by surrounding non-parenchymal liver cells, such as hepatocyte growth factor (HGF) and Oncostatin M (OsM), are essential for hepatic maturation [42]. HGF enhances hepatocyte proliferation but it inhibits biliary differentiation by blocking notch signaling [43]. OsM, which is expressed in hematopoietic cells in the fetal liver [45], promotes the hepatic differentiation from liver progenitor cells $[42,43,46]$

As mentioned above, growth factors that are necessary for in vivo hepatic development are utilized in hepatic differentiation from
ESC-derived hepatoblasts. Measurement of urea synthesis [47], ALB production [47], glycogen storage [37], uptake low-density lipoprotein (LDL) [48], uptake and secrete Indocyanine Green [48], coagulation factor VII activity [49], have been used to verify if ESC-derived hepatocyte-like cells function adequately as hepatocytes. Measurement of the ability of human immunodeficiency virus (HIV)-hepatitis C virus (HCV) pseudotype viruses to enter into human ESC-derived hepatocyte-like cells, has also been used to estimate hepatic maturation [37]. Although HGF is widely used for inducing hepatic phenotypes (e.g., ALB and dipeptidyl peptidase IV expression) [50,51], this is not enough to induce functional maturation [51,52]. To generate functional hepatocytes, combinations of FGF, HGF, and a mixture of insulin-transferrin-sodium selenite (ITS), dexamethasone, and OsM are often used [53-55]. Combination of HGF, activin A, and Wnt3a promoted the differentiation of human iPSCs into mature hepatocytelike cells [56]. Minor modifications to this strategy resulted in $70 \%$ to $-80 \%$ purity (based on estimating ALB-positive cells) of ESC-derived hepatocytes [57,58].

Because drug discovery is one of the most anticipated applications of ESC-derived hepatocyte-like cells, it is important to generate ESCderived hepatocyte-like cells that have the same characteristics as primary human hepatocytes. Even when the various hepatic functions described above are observed in ESC-derived hepatocytes, expression level of hepatocyte-related genes in ESC-derived hepatocytes is often lower than that of human hepatocytes [59]. To generate functional hepatocytes which have characteristics similar to primary human hepatocytes, exogenous transduction of transcription factor genes that can control the expression of hepatocyte-related genes is suitable for efficient differentiation of hepatocyte-like cells from ESCs. Sequential transduction of the SOX17, HEX, and HNF4a genes, which are central regulators of liver development, in ESC-derived hepatoblasts has been shown to successfully induce mature hepatocyte-like cells that have the same features as primary human hepatocytes [60] (Figure 1). Furthermore, these hepatocyte-like cells could catalyze the toxication of several compounds, suggesting that the ESC-derived hepatocytes have potential for use in drug-screening applications. Overexpression of the Foxa2, Hnf4a, and c/EBPa genes into expandable liver-derived progenitor cells resulted in mature hepatocyte phenotypes [61]. Many other studies have shown the effect of the transduction of differentiation-related genes to promote hepatic differentiation from various origins (summarized in Table 1) $[24,25,27,28,38,39,60,61,62$ 67], demonstrating that transduction of differentiation-related genes into ESCs would be a powerful strategy to generate mature hepatocytelike cells.

\section{Hepatic Differentiation from iPSCs}

The iPSC technology raises the possibility of generating patientspecific cell types of all lineages [68,69]. Because drug metabolism capacity differs among individuals [70], it is difficult to make a precise

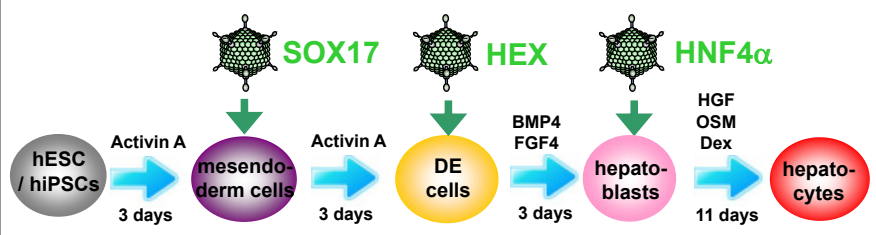

Figure 1: A protocol for hepatic differentiation of human ESCs or iPSCs by an adenovirus vector-mediated gene transfer. 


\begin{tabular}{|c|c|c|c|}
\hline Origin & Species & $\begin{array}{l}\text { hepatic transcription } \\
\text { factor genes }\end{array}$ & ref \\
\hline ESCs & mouse & FOXA2 & [27] \\
\hline ESCs & mouse & FOXA2 & [28] \\
\hline ESCs & mouse & E-cadherin & [62] \\
\hline ESCs & mouse & HEX & [38] \\
\hline ESCs & human & SOX17 & [24] \\
\hline ESCs/iPSCs & human & SOX17 & [25] \\
\hline ESCs/iPSCs & human & HNF4a & [60] \\
\hline ESCs/iPSCs & human & HEX & [39] \\
\hline $\begin{array}{l}\text { hepatic progenitor cells } \\
\text { isolated from E14 fetal } \\
\text { mouse }\end{array}$ & mouse & HNF4a & [63] \\
\hline $\begin{array}{l}\text { lineage-depleted OsM } \\
\text { receptor } \beta \text { expressing } \\
\text { bone marrow cells }\end{array}$ & mouse & HNF4a & [64] \\
\hline $\begin{array}{l}\text { human unbilical cord } \\
\text { mesenchymal stem cells }\end{array}$ & human & hTERT & [64] \\
\hline $\begin{array}{l}\text { human mesenchymal } \\
\text { stem cells }\end{array}$ & human & HNF4a & [65] \\
\hline $\begin{array}{l}\text { adult liver derived } \\
\text { progenitor cells }\end{array}$ & mouse & FOXA2, HNF4a, c/EBPa & [61] \\
\hline fibroblasts & mouse & HNF4a, FOXA1-3 & [66] \\
\hline fibroblasts & mouse & $\begin{array}{l}\text { GATA4, HNF1 } \alpha \text {, FOXA3 (+ } \\
\text { inactivation of p19Arf) }\end{array}$ & [67] \\
\hline
\end{tabular}

in liver function [86]. It has been reported that small hepatocytes could be induced to differentiate into mature hepatocytes by co-culturing with non-parenchymal cells in vitro [87]. Cell-cell interactions between embryonic cardiac mesoderm and definitive endoderm have been shown to be essential for liver development [88]. Transcription factors that are critical for hepatic development have been identified from these cell-cell interactions [88]. ES cells co-cultured with cardiac mesoderm showed spontaneous differentiation into hepatocytes [89]. These results suggest that the combined differentiation methods, such as addition of soluble factors into culture medium, transduction of differentiation-related genes or co-cultivation with other lineage cells, may further enhance the differentiation and maturation efficiency of hepatocytes.

Recently, numerous three-dimensional (3D) culture methods have been reported. Among these, the spheroid culture methods, which include the hanging-drop method and the float-culture method using culture dishes coated with non-adherent polymer, have been widely used to culture primary hepatocytes in vitro. As various micropatterning technologies have been developed, various micro-patterned substrates, employing both surface engineering and synthetic polymer chemistry for utilizing spheroid culture, have been reported [90,91]. Spheroid culture methods permit the maintenance of liver-function of primary hepatocytes in comparison with the two-dimensional (2D)culture.

The bioreactor method is also used for culturing primary hepatocytes. By studying various optimized conditions, flow conditions [92] and cell densities [93], this system has not only shown advantages in terms of maintaining the functions of primary hepatocytes in vitro in comparison with 2D-culture [94,95], but also has shown effects of spontaneous differentiation from ESCs into hepatocytes [96,97]. It has been reported that $3 \mathrm{D}$ culture using a bioreactor induces more functional maturation in hepatocytes differentiated from ESCs than 2D-culture [97]. The 3D culture methods using polymer scaffold systems have also demonstrated effectiveness both in culturing primary hepatocytes $[98,99]$ and in differentiation from ESCs into hepatocytes in vitro [100-102]. These data showed that hepatocytes could be induced from ESCs on a polymer scaffold. ALB expression was detected earlier and the mRNA expression level of ALB was higher than in 2D culture. Furthermore, cell-sheet engineering has recently been reported [103,104]. Cell-sheet 3D culture was performed by using a culture dish coated with a temperature-responsive polymer, poly (N-isopropylacrylamide) [105-107]. Some groups have adopted culture methods with a combination of 3D culture and co-culture and showed that the liver function of primary hepatocytes could be maintained more strongly and longer than without co-culture conditions [108-110]. These combined methods will likely be a more effective differentiation condition to gain mature hepatocytes from ESCs and iPSCs.

\section{Transplantation of Human ESC- or iPSC-derived Hepatocyte-like Cells}

Because of the species differences between humans and other animals, it is difficult to apply biological phenomena of animals to humans in the early phase of drug screening [111]. It is known that chimera mice with human hepatocytes would be a powerful tool to predict drug toxicity and drug metabolism in vivo [112-115]. In addition, chimera mice are useful to investigate the molecular mechanisms involved in infection with human hepatitis B virus (HBV) and HCV, because there is no suitable small animal model for such study [116-118]. However, large amounts of human hepatocytes must 
be prepared for these technologies, thus requiring large numbers of chimera mice. If it becomes possible to generate a robust chimera mouse model with hepatocyte-like cells differentiated from human ESCs or iPSCs, then chimera mice with humanized livers could be widely used in pharmaceutical development. To this end, several groups have reported the generation of chimera mice with hepatocytelike cells differentiated from human ESCs and iPSCs. Cai et al. reported that human ESC-derived hepatocyte-like cells were transplanted into the carbon tetrachloride $\left(\mathrm{CCl}_{4}\right)$-injured liver of severe combined immunodeficiency (SCID) mice and human alpha-1-antitrypsin (AAT) expression was detected in the liver [37]. Touboul et al. [119] showed that human ESC-derived hepatocyte-like cells can engraft and express human ALB and AAT in the liver of urokinase-type plasminogen activator-transgenic Rag2IL-2Rg- (uPA-Rag2IL-2 $\mathrm{Rg}^{-/}$) mice. Duan et al. [120] reported that human ESC-derived hepatocytelike cells were transplanted into the liver of NOD.CB17-Prkdc scid/ $\mathrm{NcrCrl}$ (NOD/SCID) mice and a significant level of human ALB was detected in the recipient mouse serum. Basma et al. [49] generated chimera mice and rats that secreted higher levels of human ALB than previously reported chimera mice. They sorted human ESC-derived hepatocyte-like cells based on surface asialoglycoprotein-receptor 1 (ASGPR1) expression and injected them into the spleen of UPA-SCID mice. Thereafter, they detected a much higher level of human ALB and human AAT in the mouse serum on day 75 after transplantation. They also performed transplantation into Nagase analbuminemic rats treated with both retrorsine, which can prevent proliferation of rat hepatocytes, and FK506, which can suppress immune response, after partial hepatectomy, demonstrating that large clusters of engrafted cells were observed in these rats and human ALB levels were reached at $20,000 \mathrm{ng} / \mathrm{ml}[49]$.

The growth speed of hepatocyte-like cells is slower than that of DE cells and hepatoblasts, both of which are immature stage cells as compared with hepatocyte-like cells [60]. It is likely that immature cells can proliferate better than mature cells in the mouse liver. Therefore, several groups have attempted to transplant DE cells or hepatoblasts. In one such attempt, human ESC-derived DE cells were successfully engrafted into the livers of NOD/SCID mice, which were treated with $\mathrm{CCl}_{4}$ and retrorsine, and these mice expressed human AAT in the liver [57]. Recently, Liu et al. [121] compared the engraft efficiency of human ESC-derived multi-stage hepatic cells. They transplanted human DE, hepatoblasts and hepatocyte-like cells differentiated from human ESCs into the dimethylnitrosamine-injured liver of NOD/LtSCID/IL-2Rg- ${ }^{-/}$(NSG) mice, demonstrating that at low cell dosages, the engraftment efficiency of DE cells was slightly higher than that of hepatoblasts and hepatocyte-like cells differentiated from human ESCs. These results suggest that DE cells, which have proliferative capability, can regenerate liver better than hepatocyte-like cells, which have lower proliferative capability.

These technologies, which use ESC-derived cells, can be applied to iPSC-derived hepatocyte-like cells. Si-Tayeb et al. [59] injected human ESC- and iPSC-derived hepatocyte-like cells into the liver of neonatal mice and they detected human ALB expression clusters. Liu et al. [121] also transplanted human ESC- and iPSC-derived hepatocyte-like cells into mice, and achieved similar results. These findings indicate that human iPSC-derived hepatocyte-like cells can engraft into the rodent liver in a manner similar to human ESC-derived hepatocyte-like cells.

Although human ESC- or iPSC-derived hepatocyte-like cells can engraft in the mouse liver, the human ALB levels in chimera mice engrafted with human ESC- or iPSC-derived hepatocyte-like cells are much lower than those in chimera mice engrafted with human primary hepatocytes $[49,112,117,121]$, suggesting that the efficiency of replacement in chimera mice generated with human ESC- or iPSCderived hepatocyte-like cells would be low. Therefore, the chimerism of mice with human ESC or iPSC-derived hepatocyte-like cells should be improved to apply this technology to industrial applications.

\section{Conclusions}

In this review, we have described several protocols that could promote the differentiation of human ESCs or iPSCs into endodermal and hepatic cells. These methods are all based on the in vivo developmental process of embryos. In the future, by using a combination of these protocols or through the discovery of molecular findings about liver development, more efficient protocols for hepatic differentiation could be developed for regenerative medicine and drug development.

\section{Acknowledgments}

This work was supported by grants from the Ministry of Health, Labor, and Welfare of Japan and the Ministry of Education, Sports, Science, and Technology of Japan. This work was also supported by the Japan Research Foundation for Clinical Pharmacology, the Nakatomi Foundation, and the Uehara Memorial Foundation

\section{References}

1. Hewitt NJ, Lechon MJ, Houston JB, Hallifax D, Brown HS, et al. (2007) Primary hepatocytes: current understanding of the regulation of metabolic enzymes and transporter proteins, and pharmaceutical practice for the use of hepatocytes in metabolism, enzyme induction, transporter, clearance, and hepatotoxicity studies. Drug Metab Rev 39: 159-234.

2. Terry C, Hughes RD (2009) An optimised method for cryopreservation of human hepatocytes. Methods Mol Biol 481: 25-34.

3. Baxter MA, Rowe C, Alder J, Harrison S, Hanley KP, et al. (2010) Generating hepatic cell lineages from pluripotent stem cells for drug toxicity screening Stem Cell Res 5: 4-22.

4. Safinia N, Minger SL (2009) Generation of hepatocytes from human embryonic stem cells. Methods Mol Biol 481: 169-180.

5. Thomson JA, Itskovitz-Eldor J, Shapiro SS, Waknitz MA, Swiergiel JJ, et al. (1998) Embryonic stem cell lines derived from human blastocysts. Science 282: $1145-1147$.

6. Takahashi K, Tanabe K, Ohnuki M, Narita M, Ichisaka T, et al. (2007) Induction of pluripotent stem cells from adult human fibroblasts by defined factors. Cell 131: $861-872$

7. Makino H, Toyoda M, Matsumoto $\mathrm{K}$, Saito $\mathrm{H}$, Nishino $\mathrm{K}$, et al (2009) Mesenchymal to embryonic incomplete transition of human cells by chimeric OCT4/3 (POU5F1) with physiological co-activator EWS. Exp Cell Res 315 2727-2740.

8. Nagata S, Toyoda M, Yamaguchi S, Hirano K, Makino H, et al. (2009) Efficient reprogramming of human and mouse primary extra-embryonic cells to pluripotent stem cells. Genes Cells 14: 1395-1404.

9. Sherwood RI, Chen TY, Melton DA (2009) Transcriptional dynamics of endodermal organ formation. Dev Dyn 238: 29-42.

10. Murry CE, Keller G (2008) Differentiation of embryonic stem cells to clinically relevant populations: lessons from embryonic development. Cell 132: 661-680.

11. Abe K, Niwa H, Iwase K, Takiguchi M, Mori M, et al. (1996) Endoderm-specific gene expression in embryonic stem cells differentiated to embryoid bodies. Exp Cell Res 229: 27-34.

12. Levinson-Dushnik M, Benvenisty N (1997) Involvement of hepatocyte nuclear factor 3 in endoderm differentiation of embryonic stem cells. Mol Cell Biol 17: 3817-3822.

13. Kubo A, Shinozaki K, Shannon JM, Kouskoff V, Kennedy M, et al. (2004) 
Citation: Kawabata K, Takayama K, Nagamoto Y, Saldon MS, Higuchi M, et al. (2012) Endodermal and Hepatic Differentiation from Human Embryonic Stem Cells and Human Induced Pluripotent Stem Cells. J Stem Cell Res Ther S10:002. doi:10.4172/2157-7633.S10-002

Development of definitive endoderm from embryonic stem cells in culture. Development 131: 1651-1662.

14. Varlet I, Collignon J, Robertson EJ (1997) nodal expression in the primitive endoderm is required for specification of the anterior axis during mouse gastrulation. Development 124: 1033-1044.

15. Sulzbacher S, Schroeder IS, Truong TT, Wobus AM (2009) Activin A-induced differentiation of embryonic stem cells into endoderm and pancreatic progenitors-the influence of differentiation factors and culture conditions. Stem Cell Rev 5: 159-173.

16. Tam PP, Kanai-Azuma M, Kanai Y (2003) Early endoderm development in vertebrates: lineage differentiation and morphogenetic function. Curr Opin Genet Dev 13: 393-400.

17. Chen YG, Wang Q, Lin SL, Chang CD, Chuang J, et al. (2006) Activin signaling and its role in regulation of cell proliferation, apoptosis, and carcinogenesis. Exp Biol Med 231: 534-544

18. D'Amour KA, Agulnick AD, Eliazer S, Kelly OG, Kroon E, et al. (2005) Efficient differentiation of human embryonic stem cells to definitive endoderm. Nat Biotechnol 23: 1534-1541.

19. Ishii T, Fukumitsu K, Yasuchika K, Adachi K, Kawase E, et al. (2008) Effects of extracellular matrixes and growth factors on the hepatic differentiation of human embryonic stem cells. Am J Physiol Gastrointest Liver Physiol 295: G313-321.

20. Brolen G, Sivertsson L, Bjorquist P, Eriksson G, Ek M, et al. (2010) Hepatocytelike cells derived from human embryonic stem cells specifically via definitive endoderm and a progenitor stage. J Biotechnol 145: 284-294.

21. Na J, Furue MK, Andrews PW (2010) Inhibition of ERK1/2 prevents neural and mesendodermal differentiation and promotes human embryonic stem cell selfrenewal. Stem Cell Res 5: 157-169.

22. Hay DC, Fletcher J, Payne C, Terrace JD, Gallagher RC, et al. (2008) Highly efficient differentiation of hESCs to functional hepatic endoderm requires ActivinA and Wnt3a signaling. Proc Natl Acad Sci USA 105: 12301-12306.

23. Morrison GM, Oikonomopoulou I, Migueles RP, Soneji S, Livigni A, et al. (2008) Anterior definitive endoderm from ESCs reveals a role for FGF signaling. Cell Stem Cell 3: 402-415.

24. Seguin CA, Draper JS, Nagy A, Rossant J (2008) Establishment of endoderm progenitors by SOX transcription factor expression in human embryonic stem cells. Cell Stem Cell 3: 182-195.

25. Takayama K, Inamura M, Kawabata K, Tashiro K, Katayama K, et al. (2011) Efficient and directive generation of two distinct endoderm lineages from human ESCs and iPSCs by differentiation stage-specific SOX17 transduction. PLoS One 6: e21780.

26. Hallonet M, Kaestner KH, Martin-Parras L, Sasaki H, Betz UA, et al. (2002) Maintenance of the specification of the anterior definitive endoderm and forebrain depends on the axial mesendoderm: a study using HNF3beta/Foxa2 conditional mutants. Dev Biol 243: 20-33.

27. Ishizaka S, Shiroi A, Kanda S, Yoshikawa M, Tsujinoue H, et al. (2002) Development of hepatocytes from ES cells after transfection with the HNF3beta gene. FASEB J 16: 1444-1446.

28. Kanda S, Shiroi A, Ouji Y, Birumachi J, Ueda S, et al. (2003) In vitro differentiation of hepatocyte-like cells from embryonic stem cells promoted by gene transfer of hepatocyte nuclear factor 3 beta. Hepatol Res 26: 225-231.

29. Gualdi R, Bossard P, Zheng M, Hamada Y, Coleman JR, et al. (1996) Hepatic specification of the gut endoderm in vitro: cell signaling and transcriptional control. Genes Dev 10: 1670-1682.

30. Jung J, Zheng M, Goldfarb M, Zaret KS (1999) Initiation of mammalian liver development from endoderm by fibroblast growth factors. Science 284: 19982003.

31. Asgari S, Moslem M, Bagheri-Lankarani K, Pournasr B, Miryounesi M, et al. (2011) Differentiation and transplantation of human induced pluripotent stem cell-derived hepatocyte-like cells. Stem Cell Rev in press.

32. Wells JM, Melton DA (2000) Early mouse endoderm is patterned by soluble factors from adjacent germ layers. Development 127: 1563-1572.
33. McLin VA, Rankin SA, Zorn AM (2007) Repression of Wnt/beta-catenin signaling in the anterior endoderm is essential for liver and pancreas development Development 134: 2207-2217.

34. Gouon-Evans V, Boussemart L, Gadue P, Nierhoff D, Koehler Cl, et al. (2006) BMP-4 is required for hepatic specification of mouse embryonic stem cellderived definitive endoderm. Nat Biotechnol 24: 1402-1411.

35. Zaret KS, Grompe M (2008) Generation and regeneration of cells of the liver and pancreas. Science 322: 1490-1494.

36. Huang H, Ruan H, Aw MY, Hussain A, Guo L, et al. (2008) Mypt1-mediated spatial positioning of Bmp2-producing cells is essential for liver organogenesis. Development 135: 3209-3218.

37. Cai J, Zhao Y, Liu Y, Ye F, Song Z, et al. (2007) Directed differentiation of human embryonic stem cells into functional hepatic cells. Hepatology 45: 12291239.

38. Kubo A, Kim YH, Irion S, Kasuda S, Takeuchi M, et al. (2010) The homeobox gene Hex regulates hepatocyte differentiation from embryonic stem cell-derived endoderm. Hepatology 51: 633-641.

39. Inamura M, Kawabata K, Takayama K, Tashiro K, Sakurai F, et al. (2011) Efficient generation of hepatoblasts from human ES cells and iPS cells by transient overexpression of homeobox gene HEX. Mol Ther 19: 400-407.

40. Kawabata K, Inamura M, Mizuguchi H (2012) Efficient hepatic differentiation from human iPS cells by gene transfer. Methods Mol Biol 826: 115-124.

41. Pal R, M MK, Das AK, Gupta PK, Bhonde R (2011) A simple and economical route to generate functional hepatocyte-like cells from hESCs and their application in evaluating alcohol induced liver damage. J Cell Biochem 113 19-30.

42. Si-Tayeb K, Lemaigre FP, Duncan SA (2010) Organogenesis and development of the liver. Dev Cell 18: 175-189.

43. Snykers S, De Kock J, Rogiers V, Vanhaecke T (2009) In vitro differentiation of embryonic and adult stem cells into hepatocytes: state of the art. Stem Cells 27: 577-605.

44. Cascio S, Zaret KS (1991) Hepatocyte differentiation initiates during endodermal-mesenchymal interactions prior to liver formation. Development 113: $217-225$.

45. Yoshimura A, Ichihara M, Kinjyo I, Moriyama M, Copeland NG, et al. (1996) Mouse oncostatin $\mathrm{M}$ : an immediate early gene induced by multiple cytokines through the JAK-STAT5 pathway. EMBO J 15: 1055-1063.

46. Kamiya A, Kinoshita T, Miyajima A (2001) Oncostatin M and hepatocyte growth factor induce hepatic maturation via distinct signaling pathways. FEBS Let 492: 90-94.

47. Duan Y, Ma X, Zou W, Wang C, Bahbahan IS, et al. (2010) Differentiation and characterization of metabolically functioning hepatocytes from human embryonic stem cells. Stem Cells 28: 674-686.

48. Baharvand H, Hashemi SM, Shahsavani M (2008) Differentiation of human embryonic stem cells into functional hepatocyte-like cells in a serum-free adherent culture condition. Differentiation 76: 465-477.

49. Basma H, Soto-Gutierrez A, Yannam GR, Liu L, Ito R, et al. (2009) Differentiation and transplantation of human embryonic stem cell-derived hepatocytes. Gastroenterology 136: 990-999.

50. Kumashiro Y, Teramoto K, Shimizu-Saito K, Asahina K, Teraoka H, et al. (2005) Isolation of hepatocyte-like cells from mouse embryoid body cells. Transplant Proc 37: 299-300.

51. Zhou QJ, Xiang LX, Shao JZ, Hu RZ, Lu YL, et al. (2007) In vitro differentiation of hepatic progenitor cells from mouse embryonic stem cells induced by sodium butyrate. J Cell Biochem 100: 29-42.

52. Kuai XL, Cong XQ, Li XL, Xiao SD (2003) Generation of hepatocytes from cultured mouse embryonic stem cells. Liver Transpl 9: 1094-1099.

53. Tsutsui M, Ogawa S, Inada Y, Tomioka E, Kamiyoshi A, et al. (2006) Characterization of cytochrome P450 expression in murine embryonic stem cell-derived hepatic tissue system. Drug Metab Dispos 34: 696-701. 
Citation: Kawabata K, Takayama K, Nagamoto Y, Saldon MS, Higuchi M, et al. (2012) Endodermal and Hepatic Differentiation from Human Embryonic Stem Cells and Human Induced Pluripotent Stem Cells. J Stem Cell Res Ther S10:002. doi:10.4172/2157-7633.S10-002

54. Ogawa S, Tagawa Y, Kamiyoshi A, Suzuki A, Nakayama J, et al. (2005) Crucial roles of mesodermal cell lineages in a murine embryonic stem cell-derived in vitro liver organogenesis system. Stem Cells 23: 903-913.

55. Hu AB, Cai JY, Zheng QC, He XQ, Shan Y, et al. (2004) High-ratio differentiation of embryonic stem cells into hepatocytes in vitro. Liver Int 24: 237-245.

56. Chen YF, Tseng CY, Wang HW, Kuo HC, Yang VW, et al. (2011) Rapid generation of mature hepatocyte-like cells from human induced pluripotent stem cells by an efficient three-step protocol. Hepatology in press.

57. Agarwal S, Holton KL, Lanza R (2008) Efficient differentiation of functional hepatocytes from human embryonic stem cells. Stem Cells 26: 1117-1127.

58. Shiraki N, Umeda K, Sakashita N, Takeya M, Kume K, et al. (2008) Differentiation of mouse and human embryonic stem cells into hepatic lineages. Genes Cells 13: 731-746.

59. Si-Tayeb K, Noto FK, Nagaoka M, Li J, Battle MA, et al. (2010) Highly efficient generation of human hepatocyte-like cells from induced pluripotent stem cells. Hepatology 51: 297-305.

60. Takayama K, Inamura M, Kawabata K, Katayama K, Higuchi M, et al. (2012) Efficient generation of functional hepatocytes from human embryonic stem cells and induced pluripotent stem cells by HNF4 $\alpha$ transduction. Mol Ther 20 : 127-137.

61. lacob R, Rudrich U, Rothe M, Kirsch S, Maasoumy B, et al. (2011) Induction of a mature hepatocyte phenotype in adult liver derived progenitor cells by ectopic expression of transcription factors. Stem Cell Res 6: 251-261.

62. Dasgupta A, Hughey R, Lancin P, Larue L, Moghe PV (2005) E-cadherin synergistically induces hepatospecific phenotype and maturation of embryonic stem cells in conjunction with hepatotrophic factors. Biotechnol Bioeng 92: 257 266

63. Suetsugu A, Nagaki M, Aoki H, Motohashi T, Kunisada T, et al. (2008) Differentiation of mouse hepatic progenitor cells induced by hepatocyte nuclear factor-4 and cell transplantation in mice with liver fibrosis. Transplantation 86: 1178-1186.

64. Khurana S, Jaiswal AK, Mukhopadhyay A (2010) Hepatocyte nuclear factor4alpha induces transdifferentiation of hematopoietic cells into hepatocytes. J Biol Chem 285: 4725-4731.

65. Chen ML, Lee KD, Huang HC, Tsai YL, Wu YC, et al. (2010) HNF-4alpha determines hepatic differentiation of human mesenchymal stem cells from bone marrow. World J Gastroenterol 16: 5092-5103.

66. Sekiya S, Suzuki A (2011) Direct conversion of mouse fibroblasts to hepatocytelike cells by defined factors. Nature 475: 390-393.

67. Huang P, He Z, Ji S, Sun H, Xiang D, et al. (2011) Induction of functional hepatocyte-like cells from mouse fibroblasts by defined factors. Nature 475 : 386-389.

68. Yamanaka S, Blau HM (2010) Nuclear reprogramming to a pluripotent state by three approaches. Nature 465: 704-712.

69. Liu H, Ye Z, Kim Y, Sharkis S, Jang YY (2010) Generation of endoderm-derived human induced pluripotent stem cells from primary hepatocytes. Hepatology 51: 1810-1819.

70. Xie HG, Kim RB, Wood AJ, Stein CM (2001) Molecular basis of ethnic differences in drug disposition and response. Annu Rev Pharmacol Toxicol 41: 815-850.

71. Chen YF, Tseng CY, Wang HW, Kuo HC, Yang VW, et al. (2011) Rapid generation of mature hepatocyte-like cells from human induced pluripotent stem cells by an efficient three-step protocol. Hepatology in press.

72. Takata A, Otsuka M, Kogiso T, Kojima K, Yoshikawa T, et al. (2011) Direct differentiation of hepatic cells from human induced pluripotent stem cells using a limited number of cytokines. Hepatol Int 5: 890-898.

73. Espejel S, Roll GR, McLaughlin KJ, Lee AY, Zhang JY, et al. (2010) Induced pluripotent stem cell-derived hepatocytes have the functional and proliferative capabilities needed for liver regeneration in mice. J Clin Invest 120: 3120-3126.

74. Greenhough S, Medine CN, Hay DC (2010) Pluripotent stem cell derived hepatocyte like cells and their potential in toxicity screening. Toxicology 278 : 250-255.
75. Si-Tayeb K, Noto FK, Nagaoka M, Li J, Battle MA, et al. (2010) Highly efficien generation of human hepatocyte-like cells from induced pluripotent stem cells. Hepatology 51: 297-305.

76. Sullivan GJ, Hay DC, Park IH, Fletcher J, Hannoun Z, et al. (2010) Generation of functional human hepatic endoderm from human induced pluripotent stem cells. Hepatology 51: 329-335.

77. Song Z, Cai J, Liu Y, Zhao D, Yong J, et al. (2009) Efficient generation of hepatocyte-like cells from human induced pluripotent stem cells. Cell Res 19 1233-1242.

78. Choi SM, Kim Y, Liu H, Chaudhari P, Ye Z, et al. (2011) Liver engraftment potential of hepatic cells derived from patient-specific induced pluripotent stem cells. Cell Cycle 10: 2423-2427.

79. Ghodsizadeh A, Taei A, Totonchi M, Seifinejad A, Gourabi H, et al. (2010) Generation of liver disease-specific induced pluripotent stem cells along with efficient differentiation to functional hepatocyte-like cells. Stem Cell Rev 6: 622 632

80. Rashid ST, Corbineau S, Hannan N, Marciniak SJ, Miranda E, et al. (2010) Modeling inherited metabolic disorders of the liver using human induced pluripotent stem cells. J Clin Invest 120: 3127-3136.

81. Guguen-Guillouzo C, Clement B, Baffet G, Beaumont C, Morel-Chany E, et al. (1983) Maintenance and reversibility of active albumin secretion by adult rat hepatocytes co-cultured with another liver epithelial cell typ. Exp Cell Res 143: $47-54$.

82. Rojkind M, Novikoff PM, Greenwel P, Rubin J, Rojas-Valencia L, et al. (1995) Characterization and functional studies on rat liver fat-storing cell line and freshly isolated hepatocyte coculture systems. Am J Pathol 146: 1508-1520.

83. Matsuo R, Ukida M, Nishikawa Y, Omori N, Tsuji T (1992) The role of kupffer cells in complement activation in D-galactosamine/lipopolysaccharide-induced hepatic injury of rats. Acta Med Okayama 46: 345-354

84. Bhatia SN, Yarmush ML, Toner M (1997) Controlling Cell Interactions by Micropatterning in Co-Cultures: Hepatocytes and 3T3 Fibroblasts. J Biomed Mater Res 34: 189-199.

85. Yu YD, Kim KH, Lee SG, Choi SY, Kim YC, et al. (2011) Hepatic differentiation from human embryonic stem cells using stromal cells. J Surg Res 170: 253261.

86. Bhatia SN, Balis UJ, Yamush ML, Toner M (1999) Effect of Cell-Cell Interactions in Preservation of Cellular Phenotype: Co-Cultivation of Hepatocytes and NonParenchymal Cells. FASEB J 134: 1883-1900.

87. Mitaka T, Sato F, Mizuguchi T, Yokono T, Mochizuki Y (1999) Reconstruction of hepatic organoid by rat small hepatocytes and hepatic nonparenchyma cells. Hepatology 29: 111-125.

88. Zaret KS (2000) Liver specification and early morphology. Mech Dev 92: 83-88

89. Fair JH, Cairns BA, LaPaglia M, Wang J, Meyer AA, et al. (2003) Induction of hepatic differentiation in embryonic stem cells by co-culture with embryonic cardiac mesoderm. Surgery 134: 189-196.

90. Jones CN, Tuleuova N, Lee JY, Ramanculov E, Reddi AH (2009) Cultivating liver cells on printed arrays of hepatocyte growth factor. Biomaterials 30: 3733 3741.

91. Otsuka H, Hirano A, Nakasaki Y, Okano T, Horiike Y, et al. (2004) TwoDimensional Multiarray Formation of Hepatocyte Spheroids on a Microfabricated PEG-Brush Surface. Chembiochem 5: 850-855.

92. Fiegel HC, Havers J, Kneser U, Smith MK, Moeller T, et al. (2004) Influence of Flow Conditions and Matrix Coatings on Growth and Differentiation of ThreeDimensionally Cultured Rat Hepatocytes. Tissue Eng 10: 165-174.

93. Ring A, Gerlach J, Peter G, Pazin BJ, Minervini CF, et al. (2010) Hepatic Maturation of Human Fetal Hepatocytes in Four-Compartment ThreeDimensional Perfusion Culture. Tissue eng Part C Methods 16: 835-845.

94. Kiyota A, Matsushita T, Ueoka R (2007) Induction and High Density Culture of Human Hepatoblasts from Fetal Hepatocytes with Suppressing Transformation. Bio Pharm Bull 30: 2308-2311. 
Citation: Kawabata K, Takayama K, Nagamoto Y, Saldon MS, Higuchi M, et al. (2012) Endodermal and Hepatic Differentiation from Human Embryonic Stem Cells and Human Induced Pluripotent Stem Cells. J Stem Cell Res Ther S10:002. doi:10.4172/2157-7633.S10-002

95. Garlach JC (1997) Long-term liver cell cultures in bioreactors and possible application for liver support. Cell biol Toxicol 13: 349-355

96. Cui T, Yan Y, Zhang R, Liu L, Xu W, et al. (2009) Rapid Prototyping of a DoubleLayer Polyurethane-Collagen Conduit for Peripheral Nerve Regeneration. Tissue Eng Part C Methods 15: 1-9

97. Miki T, Ring A, Gerlach J (2011) Hepatic differentiation of Human Embryonic Stem Cells is promoted by three-dimensional dynamic perfusion culture conditions. Tissue Eng Part C Methods 17: 557-568.

98. Bierwolf J, Lutgehetmann M, Feng K, Erbes J, Deichmann S, et al. (2011) Primary rat hepatocyte culture on 3D nanofibrous polymer scaffolds for toxicology and pharmaceutical research. Biotech Bioeng 108: 141-150.

99. Baharvand H, Hashemi SM, Ashtiani SK, Farrokhi A (2006) Differentiation of human embryonic stem cells into hepatocytes in 2D and 3D culture systems in vitro. Int J Dev Biol 50: 645-652.

100. Liu T, Zhang S, Chen X, Li G, Wang Y (2010) Hepatic Differentiation of Mouse Embryonic Stem Cells in Three-Dimensional Polymer Scaffolds. Tissue Eng Part A 16: 1115-1122.

101. Lee H, Cusick RA, Utsunomiya H, Ma PX, Langer R, et al. (2003) Effect of Implantation Site on Hepatocytes Heterotopically Transplanted on Biodegradable Polymer Scaffolds. Tissue Eng 9: 1227-1232.

102. Matsumoto K, Mizumoto H, Nakazawa K, ljima H, Funatsu K, et al. (2008) Hepatic differentiation of mouse embryonic stem Cells in a three-dimensional culture system using polyurethane foam. J Biosci Bioeng 105: 350-354.

103. Yang J, Yamato M, Kohno C, Nishimoto A, Sekine H, et al. (2005) Cell sheet engineering: Recreating tissues without biodegradable scaffolds. Biomaterials 26: $6415-6422$.

104. Shimizu T, Yamato M, Isoi Y, Akutsu T, Setomaru T, et al. (2002) Fabrication of pulsatile cardiac tissue grafts using a novel 3-dimensional cell sheet manipulation technique and temperature-responsive cell culture surfaces. Circ Res 90: e40-48.

105. Yamada N, Okano T, Sakai H, Karikusa F, Sawasaki Y, et al. (1990) Thermoresponsive polymeric surfaces; control of attachment and detachment of cultured cells. Macromol Chem Rapid Commum 11: 571-576.

106. Okano T, Yamada N, Sakai H, Sakurai Y (1993) A novel recovery system for cultured cells using plasma-treated polystyrene dishes grafted with poly (N-isopropylacrylamide). J Biomed Mater Res 27: 1243-1251.

107. Hirose M, Kwon OH, Yamato M, Kikuchi A, Okano T (2000) Creation of designed shape cell sheets that are noninvasively harvested and moved onto another surface. Biomacromolecules 1: 377-381.

108. Lu H, Chua K, Zhang P, Lim W, Ramakrishna, et al. (2005) Three-dimensiona co-culture of rat hepatocyte spheroids and NIH/3T3 fibroblasts enhances hepatocyte functional maintenance. Acta Biomater 1: 399-410.
109. Thomas RJ, Bhandari R, Barret DA, Benett AJ, Fry JR, et al. (2005) The effect of three-dimensional co-culture of hepatocytes and hepatic stellate cells on key hepatocyte functions in vitro. Cells Tissues Organs 181: 67-79.

110. Xiong A, Austin TW, Lagasse E, Uchida N, Tamaki S, et al (2008) Isolation of Human Fetal Liver Progenitors and Their Enhanced Proliferation by ThreeDimensional Coculture with Endothelial Cells. Tissue Eng Part A 14: 995-1006.

111. Bogaards JJ, Bertrand M, Jackson P, Oudshoorn MJ, Weaver RJ, et al. (2000) Determining the best animal model for human cytochrome P450 activities: a comparison of mouse, rat, rabbit, dog, micropig, monkey and man. Xenobiotica 30: 1131-1152.

112. Tateno C, Yoshizane Y, Saito N, Kataoka M, Utoh R, et al. (2004) Near completely humanized liver in mice shows human-type metabolic responses to drugs. Am J Pathol 165: 901-912.

113. Lootens L, Van Eenoo P, Meuleman P, Leroux-Roels G, Delbeke FT (2009) The UPA(+/+)-SCID mouse with humanized liver as a model for in vivo metabolism of 4-androstene-3,17-dione. Drug Metab Dispos 37: 2367-2374.

114. Lootens L, Van Eenoo P, Meuleman P, Pozo OJ, Van Renterghem P, et al. (2009) Steroid metabolism in chimeric mice with humanized liver. Drug Test Anal. 1: 531-537.

115. Sato Y, Yamada H, Iwasaki K, Tateno C, Yokoi T, et al. (2008) Human hepatocytes can repopulate mouse liver: histopathology of the liver in human hepatocyte-transplanted chimeric mice and toxicologic responses to acetaminophen. Toxicol Pathol 36: 581-591.

116. Mercer DF, Schiller DE, Elliott JF, Douglas DN, Hao C, et al. (2001) Hepatitis $C$ virus replication in mice with chimeric human livers. Nat Med 7: 927-933.

117. Bissig KD, Wieland SF, Tran P, Isogawa M, Le TT, et al. (2010) Human liver chimeric mice provide a model for hepatitis $B$ and $C$ virus infection and treatment. J Clin Invest 120: 924-930.

118. Washburn ML, Bility MT, Zhang L, Kovalev GI, Buntzman A, et al. (2011) A humanized mouse model to study hepatitis $C$ virus infection, immune response, and liver disease. Gastroenterology 140: 1334-1344.

119. Touboul T, Hannan NR, Corbineau S, Martinez A, Martinet C, et al. (2010) Generation of functional hepatocytes from human embryonic stem cells under chemically defined conditions that recapitulate liver development. Hepatology 51: 1754-1765.

120.Duan Y, Catana A, Meng Y, Yamamoto N, He S, et al. (2007) Differentiation and enrichment of hepatocyte-like cells from human embryonic stem cells in vitro and in vivo. Stem Cells 25: 3058-3068.

121. Liu H, Kim Y, Sharkis S, Marchionni L, Jang YY (2011) In vivo liver regeneration potential of human induced pluripotent stem cells from diverse origins. Sci Transl Med 3: 82ra39.
This article was originally published in a special issue, Embryonic and Induced Pluripotent Stem Cells handled by Editor(s). Dr. Jianlong Wang, Mount Sinai School of Medicine, United States 